\title{
OBECNOŚĆ/NIEOBECNOŚĆ RELIGII W DYSKURSIE PEDAGOGICZNYM
}

Przemiany, jakim podlega współczesny świat, wywierają wpływ także i na kształt dyskusji o edukacji. Autorzy zabierający głos na ten temat coraz częściej nawiązują do najbardziej dramatycznych wyzwań, jakie dziś stają przed edukacją lub też zagrożeń, z którymi musi ona się zmagać. W dobie wyraźnego kryzysu edukacyjnego, mniej lub bardziej kompetentnych i rzetelnych dyskusji o stanie lub kryzysie edukacji, także religijnej, wskazuje się niekiedy na zagadnienia bardziej fundamentalne, jak na przykład relacje między kulturą i religią, edukacją i religią, pedagogiką i filozofią, czy pedagogiką a teologią. Jest to niekiedy dobrym, a nawet koniecznym punktem wyjścia dla dyskusji o kształcie edukacji właściwej na dziś.

W ten nurt dyskusji ostatnio wpisują się prace ks. prof. Dariusza Stępkowskiego, salezjanina, który jest pracownikiem naukowym w Uniwersytecie Kardynała Stefana Wyszyńskiego w Warszawie. W swoich publikacjach, a szczególnie w pracy publikacji pod tytułem Pedagogika ogólna

* Ks. prof. dr hab. Jerzy Bagrowicz, profesor zwyczajny, pracownik naukowy na Wydziale Nauk Pedagogicznych i Wydziale Teologicznym Uniwersytetu Mikołaja Kopernika w Toruniu, w latach 2001-2005 dziekan Wydziału Teologicznego. 
i religia. (Re)konstrukcja zapomnianego watku na podstawie teorii Johanna F. Herbarta $i$ Friedricha D. E. Schleiermachera (2010) podejmuje zagadnienia bardzo ważne dla współczesnych dyskusji o wychowaniu i pedagogice, o relacjach między religią a kulturą, pedagogiką ogólną a religią. Pytania dotyczące wskazanego wyżej obszaru badań podejmuje on na tle analizy czy rekonstrukcji teorii Johanna F. Herbarta i Friedricha D. E. Schleiermachera. Rezultaty podjętych analiz są ważne także dla współczesnych poszukiwań w zakresie pedagogiki ogólnej, a także pedagogiki religii. Odbyte przez niego studia w kraju i zagranicą oraz badania w zakresie pedagogiki i teologii - jak sam przyznaje - umożliwiły mu zrozumienie obecności komponentu pedagogicznego w myśleniu teologicznym i komponentu teologicznego $\mathrm{w}$ pedagogice.

We współczesnej polskiej literaturze pedagogicznej i pedagogiczno-religijnej mało jest publikacji, które podejmowałyby tak fundamentalne zagadnienia, a ten nurt refleksji jest, ze względu na aktualne potrzeby, szczególnie pożądany. Dlatego warto zwrócić uwagę na wyżej cytowaną pracę D. Stępkowskiego, ponieważ jest to ważny głos pedagoga, naukowca i praktyka, dotyczący roli religii w kształceniu i wychowaniu młodego pokolenia. Jest to akurat dziś "gorący" temat także życia publicznego w Polsce. Praca, do której będziemy się odwoływać, składa się z wprowadzenia, siedmiu rozdziałów, zakończenia, zestawu bibliografii oraz streszczenia w języku niemieckim.

We wstępie (por. s. 10) autor określa jasno problem pracy $\mathrm{w}$ formie pytania: czy sprawy religijne należa do kompetencji pedagogiki? Autor stwierdza, że od odpowiedzi na główne pytanie tej pracy zależy odpowiedź na pytania bardziej szczegółowe, m.in. jaką rolę może dogrywać religia w kształceniu i wychowaniu młodego pokolenia? Czy Kościół ma prawo współtworzyć oświatę publiczną? Rozszerzając postawione pytania badawcze autor celnie podejmuje problem obecności/nieobecności religii w dyskursie pedagogicznym (por. s. 11-14). Odnotowuje on zjawisko zagubienia religijnego komponentu wychowania i pedagogicznego komponentu wiary we współczesnych dyskursach pedagogicznych oraz teologicznych. Jest świadom tego, że daje czytelnikowi w tym miejscu jedynie zarys dyskusji i pytań na temat obecności i żywotności zagadnień religijnych we współczesnych dyskursach pedagogicznych (por. s. 18). We wprowadzeniu autor sporo miejsca poświęca dyskusji o metodologicznych podstawach dzisiejszej pedagogiki ogólnej, nazywanej przez naszego autora za Bennerem pedagogiką systematyczną (por. s. 25). Za Bennerem i Gadamerem autor stwierdza, że u podstaw refleksji pedago- 
gicznej leży „pytajność”: „Gdyby nie było pytania o podstawy i specyfikę myślenia i działania pedagogicznego, nie byłoby możliwe prowadzenie dociekań w tej kwestii” (s. 29). Warto przypomnieć, że owa „pytajność”, o której mówi autor, od początku jest uznawana za podstawę naukowej refleksji, nie tylko w pedagogice czy w filozofii, ale także w naukach przyrodniczych. Wolno jednak sądzić, że jest ona szczególnie ważna w humanistyce.

Autor, prezentując strukturę swej pracy wyjaśnia, dlaczego odpowiedź na podstawowe pytanie badawcze daje w oparciu o pisma Herbarta i Schleiermachera: „Wybór tych właśnie dwóch klasyków podyktowany jest z jednej strony tym, że obaj są w historiografii pedagogicznej uznawani za równorzędnych prekursorów nowożytnej pedagogiki ogólnej [...] z drugiej zaś tym, że w swoich koncepcjach expressis verbis podejmują tematykę religijną, wskazując na jej odniesienia do wychowania i kształcenia oraz ich teorii" (s. 30-31).

We wprowadzeniu autor ukazuje więc w dość szerokiej perspektywie dotychczasowy stan badań nad tym problemem, a co jest szczególnie ważne - określa jasno bazę źródłową, zakres problematyki, w obszarze której zamierza się poruszać. Jest tu bardzo szerokie, wieloaspektowe wprowadzenie czytelnika w podjęte przez autora zagadnienie, kontekst metodologiczny stawianych pytań badawczych, wyjaśnienie podstawowych pojęć.

Problematyka pracy została ujęta - jak to wyżej wskazałem w siedmiu rozdziałach. Cztery pierwsze rozdziały pracy poświęca autor przedstawieniu teorii Herbarta, a trzy następne teorii Schleiermachera. Jak sam autor podkreśla, podział ten może być uzasadniony poglądami obu uczonych na temat centralnego pytania tej pracy, a mianowicie więzi między pedagogiką ogólną a religią. Zdaniem D. Stępkowskiego, u Schleiermachera można dostrzec rozszerzanie się perspektywy widzenia problemu, uwzględnia on wyraźniej niż Herbart „,kontekst społeczno-historyczny i językowy, rozważa kształcenie i wychowanie religijne jako zadanie ogólnospołeczne (publiczne)”, podczas gdy Herbart „skupia uwagę na jednostce $\mathrm{i}$ indywidualnym procesie kształcenia/kształtowania" (s. 32). W ten sposób autor wyjaśnia i uzasadnia układ swej pracy. W I rozdziale autor ukazuje Estetyczne podstawy pedagogiki Herbarta. Nie chodzi mu tu o twórczość artystyczną, ale wskazuje na syntezę etyki i estetyki we wszystkich formach ludzkiego działania. „Uzyskiwaną w ten sposób jakość określa mianem piękna etycznego” (s. 37). Model estetyki pedagogicznej wciela on w życie od pierwszych prac na temat 
Pestalozziego i jego poglądów na wychowanie. Estetyczne podejście do kształcenia i wychowania - jak to wyjaśnia D. Stępkowski - wynika u Herbarta z ujęcia przez niego estetyki filozoficznej. W estetyce ogólnej widzi on naukę o religii, naukę o cnocie i nauki o sztukach. Jak podkreśla D. Stępkowski, „szczególnie interesująca jest [...] funkcja estetyczna, jaką wyznacza Herbart religii. [...] religia bowiem poza wpływem moralnym wywiera jeszcze wpływ estetyczny [...] gdyby nie miała oddziaływać estetycznie, nie mogłaby w ogóle działać moralnie" (s. 40). W rozdziale I mamy więc bardzo szczegółowo uzasadnione źródła estetycznych podstaw pedagogiki w ujęciu Herbarta: od wpływów pism Platona aż po współczesne Herbartowi ujęcie metafizyki. Jak wyjaśnia D. Stępkowski

Herbartowska koncepcja nauczania wychowującego bazuje na możliwości płynnego przejścia od kształcenia (nauczania) do kształtowania (wychowania). Warunkiem zaś tego jest takie samo podłoże estetyczne działań ukierunkowanych na piękno teoretyczno-estetyczne i estetyczno-etyczne. W tym ostatnim jednoczy się dążenie do cnoty i poczucie religijne $\mathrm{w}$ sposób do tej pory nieokreślony. Wyjaśnienie tego oznacza właściwe znalezienie odpowiedzi na pytanie o relacje między wychowaniem a religią (s. 57).

Autor skupia się następnie (rozdz. II) na występującym głównie u Herbarta terminie ukształcalność (Bildsamkeit). Polskie tłumaczenie tego terminu wprowadził w Polsce Bogdan Nawroczyński (1967). Zdaniem D. Stępkowskiego neologizm ten dobrze oddaje myśl Herbarta, nawiązuje on bowiem do toczącej się od połowy $X X$ wieku debaty pedagogicznej na temat formowania podmiotu przez ukształcanie (Bildung) (por. s. 64). Ukształcalność będzie więc rozumiana jako plastyczność wychowanka, jego podatność na wpływy kształcące.

Ważnym zagadnieniem, które zajmuje naszego autora (rozdz. III), jest problematyka wychowania moralnego i roli religii w tymże wychowaniu. Autor, analizując poglądy Herbarta, podkreśla, że zdaniem tegoż myśliciela piękno etyczne jest odczuciem, które powstaje w podmiocie niezależnie od jego woli - obiektywnie i skłania podmiot do dobra. Autor polemizuje z poglądami jakoby teoria Herbarta była wyrazem jego intelektualizmu etycznego (etycyzmu) i skłonności do umoralniania (por. s. 98). Sporo miejsca w tym rozdziale D. Stępkowski poświęca poglądom Herbarta na znaczenie tzw. idei praktycznych, które umożliwiają podmiotowi ocenę samego siebie. Autor podkreśla, że zdaniem Herbarta kwintesencją wszystkich idei praktycznych jest religia, a dokładnie idea 
Boga, „rozumiana jednak nie tylko jako pojęcie, lecz przede wszystkim Stwórca świata i Zbawiciel człowieka"(por. s. 104-105). Konkludując D. Stępkowski podkreśla, że w ujęciu Herbarta religia jako punkt odniesienia, wykracza tak poza moralność, jak i sferę estetyczną (por. s. 106).

Rozdział czwarty omawianej pracy ukazuje religię w Herbartowskiej koncepcji nauczania wychowującego. Na początku ks. D. Stępkowski próbuje ustalić źródła wątpienia Herbarta w dokonania epoki Oświecenia. Odnajduje pewne pokrewieństwo nieufności do tych osiągnięć w myśli Kanta, który w 1793 r. napisał: „Świat pogrąża się w złu”. Nasz autor jednak analizując pisma Herbarta $\mathrm{w}$ innym miejscu dochodzi do wniosku, że patrzył on na zmiany świata jemu współczesnego z pewną dozą optymizmu (por. s. 108-109). Sporo miejsca poświęca nasz autor ukazaniu różnicy $\mathrm{w}$ ujęciu pedagogiki u Kanta i Herbarta (por. s. 109-116), a także nauczania wychowującego. Zdaniem Herbarta to ostatnie nie powinno „opierać się na wpajaniu takiej czy innej doktryny, lecz rozwijaniu $\mathrm{w}$ wychowanku umiejętności filozofowania.[...] Kluczową rolę odgrywa w nim przestrzeganie "postulatu religijnego»" (s. 115). Dla Herbarta - jak podkreśla D. Stępkowski - wiara nie jest czymś jedynie subiektywnym ani wytworem człowieka, lecz tym, co dociera do niego z zewnątrz. Podkreśla, że religijność wymaga krytyki ze strony rozumu, istnieje bowiem niebezpieczeństwo, że „największy nonsens [...] może stać się „największą pobożnością" (s. 117).

Sporo miejsca D. Stępkowski poświęca przedstawieniu myśli Herbarta na temat zainteresowań religijnych i miejscu religii $\mathrm{w}$ nauczaniu szkolnym. Zdaniem Herbarta dziecko od najmłodszych lat intuicyjnie odczuwa Istotę Najwyższą. Ukazuje on znaczenie nie tylko indywidualnego, ale i społecznego (wspólnotowego) wymiaru religijności. Dla Herbarta - zdaniem Stępkowskiego - potrzeba religii w nauczaniu wynika nie z zadań socjalizacyjnych religii, ale przede wszystkim ze względów czysto pedagogicznych. Wprowadzenie $\mathrm{w}$ kult nie należy - zdaniem Herbarta - do zadań nauczania, ale jest to zadanie rodziców i Kościoła. Jednak - jak podkreśla Stępkowski - nie wynika z tego, że Herbart nie widzi związku między tymi dwoma zakresami i zadaniami. Nie odrzuca on także znaczenia i wagi kultu, czy „świętowania religii” (por. s. 119). Podkreśla on wagę wczesnego zetknięcia się dziecka z ideą Boga, która powinna mieć swoje trwałe miejsce wśród najwcześniejszych myśli dziecka, z którymi wiąże się osobowość stającego się człowieka" (s. 120). Jak podkreśla Herbart religia nie zniknie nigdy $\mathrm{z}$ orbity ludzkich zainteresowań i tym samym wpisana jest w nauczanie wychowujące (por. s. 122). 
Kolejne trzy rozdziały D. Stępkowski poświęca twórczości Friedricha D. E. Schleiermachera. W twórczości tegoż teologa, filozofa i pedagoga protestanckiego religia przewija się jak nić przez wszystkie jego dzieła (por. s. 138). Na początek, w rozdziale piątym, D. Stępkowski ukazuje relację między poznaniem, kształceniem i religią w ujęciu Schleiermachera. Myśliciel ten zwracał uwagę na rozłam, jaki w czasach nowożytnych nastąpił między religią i kulturą. Jego zdaniem najwidoczniejsze skutki tego rozłamu można dostrzec na polu edukacji, gdzie za „niezbity aksjomat przyjmuje się (aż do dziś), że religia i nowocześnie rozumiana paideia w znacznym stopniu się wykluczają" (tamże). Dariusz Stępkowski cytuje ciekawą myśl Schleiermachera na temat zmysłu religijnego w człowieku: „Człowiek rodzi się z predyspozycją do religii, podobnie jak z każdą inną, i jeśli tylko jego zmysł nie zostanie gwałtownie stłumiony [...], to nieuchronnie predyspozycja ta musi rozwinąć się w każdym na jego własny sposób" (s. 141-142). Stępkowski przywołuje tu pojęcie ukształcalności, jako fundament rozwoju religijności w człowieku. Sporo miejsca ks. Stępkowski poświęca wyjaśnieniu jak Schleiermacher rozumie ukształcalność w zakresie religii (por. s. 143-152). Zarzucał on swej epoce, że marnotrawi czas ukształcalności pedagogicznej. Wykształconym natomiast zarzucał pogardę, z jaką odnoszą się do religii. Ks. Stępkowski cytuje w swej pracy ważne zdanie tegoż autora na ten temat: „Mieć tylko jeden punkt widzenia na wszystko [...] to jest droga oddalania się w prostym kierunku od wszechświata i tonięcia w najżałośniejszym ograniczeniu, stawania się glebae adscriptus do miejsca, na którym właśnie przypadkowo stoimy" (s. 149). W pracy Stępkowskiego znajdziemy bardzo szeroko opisane poglądy Schleiermachera na temat istoty religii i jej znaczenia dla kształtowania człowieka (por. np. s. 152-173).

Kontynuując rozważania na temat związku religii z kształceniem, ks. Stępkowski ukazuje spojrzenie tegoż na wychowanie jako dialog pokoleń (rozdział szósty). To przestrzeń wzajemnych oddziaływań, dialogu międzypokoleniowego. Problematykę tę poddaje dogłębnej analizie w oparciu o myśl filozoficzno-etyczną oraz pedagogiczną i religijną Schleiermachera. Następnie przybliża sens tego dialogu w wymiarze praktycznym. Zdaniem Schleiermachera dostrzeżenie przez niego wagi i mechanizmów dialogu międzypokoleniowego jest momentem narodzin pedagogiki intergeneracyjnej, opartej na fundamencie etyki: „Pedagogika zasadza się na wglądzie w etyczność" (s. 198). Dialog międzypokoleniowy domaga się - zdaniem Schleiermachera - aktywnego udzialu młodego pokolenia w dialogu z dorosłymi, a nie tylko aktywności starszej generacji. 
Podobnie jak to było w prezentacji myśli Herbarta, i w wypadku refleksji na temat Schleiemachera, ks. Stępkowki w ostatnim, siódmym rozdziale swej pracy ukazuje Schleiermacherowskie ujęcie roli religii w dyskursie społecznym. Pomijając tu wartość i potrzebę analizy pojęć, które wprowadza Schleiermacher w tym miejscu (np. pojęcie "towarzyskości"), czy też rozważań na temat możliwości i granic działania pedagogicznego, chciałbym zwrócić uwagę na ten fragment tej pracy, w którym D. Stępkowski ukazuje zagadnienie kształtowania pojęć religijnych $\mathrm{w}$ ujęciu Schleiermachera. Jest to bardzo interesujący fragment tej pracy . Mamy tu nie tylko zreferowane i przeanalizowane poglądy Schleiermachera, ale i bogato ilustrowane fragmentami prac tego uczonego. Poświęca on wiele miejsca rozróżnieniu "między indywidualną a uniwersalną stroną wychowania” (por. s. 229-230). Oto ciekawsze fragmenty: „Ponieważ Kościół [...] jest społecznością całkowicie wolną, w której nie ma żadnego przymusu wewnętrznego, również kształcenie przekonania religijnego musi się wystrzegać stosowania jakichkolwiek form nacisku. Dlatego jest ono niejako skazane na «swobodne wpływy życiowe», których centrum jest rodzina. Zgodnie z tym lekcje religii w szkołach publicznych, «których młodzieży udzielają funkcjonariusze Kościoła», mogą być rozumiane wyłącznie jako "suplement wychowania rodzinnego»" (s. 229). Schleiermacher podkreśla - jak to akcentuje ks. Stępkowski - potrzebę i znaczenie kształcenia szkolnego w zakresie religii. Do tego zagadnienia nawiązuje ks. Stępkowski w zakończeniu swej pracy (por. s. 245).

Ksiądz Dariusz Stępkowski dotyka bardzo ważnego problemu, a mianowicie relacji pedagogiki ogólnej do religii. Ciągle nie podejmuje się odpowiedzi na pytanie "czego z szeroko ujmowanego zakresu religii ma dotyczyć refleksja ogólno-pedagogiczna". D. Stępkowski podkreśla w swej pracy potrzebę sprecyzowania odpowiedzi na powyższe pytanie, podkreślając jednocześnie, że niedostatecznie jasno sprecyzowane jest pojęcie pedagogiki ogólnej i „brakuje kryterium umożliwiającego rozróżnienie problemów należących do zakresu pedagogiki ogólnej od zagadnień będących domeną pokrewnych nauk zajmujących się pograniczem między wychowaniem a religią, takich jak [...] katechetyka, pedagogika religii (religijna) i pedagogika chrześcijańska" (s. 236). Autor pracy słusznie sądzi, że rozróżnienie owo pomogłoby we współpracy ze wspomnianymi wyżej subdyscyplinami.

Dla wartości tej pracy niebagatelne są cenne uwagi, które autor zamieszcza w zakończeniu. Wydaje się nawet, że zwieńczeniem tej pracy powinien być rozdział odpowiadający na postawione we wstępie 
pytanie badawcze : „,zy sprawy religijne należą do kompetencji pedagogiki" (s. 10). Materiał zawarty w zakończeniu jest bogaty i po pewnym poszerzeniu nadawałby się na osobny rozdział. Przydałoby się $\mathrm{w}$ tym rozdziale rozbudować myśl zawartą w zakończeniu: „Legitymizacja religii jako przedmiotu edukacji szkolnej nie ma już więcej nic wspólnego z wyznaczonym odgórnie minimum programowym, lecz czerpie swoje uzasadnienie z samej rzeczywistości, mówiąc dokładnie z doświadczenia, którego integralną częścią jest religia" (por. s. 254). Wydaje się, że nie wykraczałoby to poza ramy problemowe tej pracy. Jest to o tyle ważne, że powracają pomysły rezygnacji z obecności edukacji religijnej w strukturze oświaty publicznej. Są to żądania polityków, którzy nie liczą się z racjami pedagogii rozwoju człowieka i obecności w nim elementów religijnych, ale raczej wynikają z chęci przypodobania się tej części elektoratu, która jest niechętna Kościołowi czy obecności religii w przestrzeni publicznej. W pracy D. Stępkowskiego znajdujemy pogłębioną refleksję na tematy podejmowane $\mathrm{w}$ dyskusji toczonej w płaszczyźnie życia publicznego.

Patrząc od tej strony, praca D. Stępkowskiego, choć pisana często językiem hermetycznym i trudnym $\mathrm{w}$ odbiorze, jest przedsięwzięciem nowatorskim. Autor dokonał ogromnego trudu przedstawienia i przybliżenia szeroko pojętej problematyki relacji pedagogiki ogólnej i pedagogiki religii. Jak to już podkreśliłem wcześniej, podejmowane dotąd próby ukazania relacji religia-edukacja czy pedagogika-teologia nie wyczerpywały problematyki. Niniejsza praca jej nie zamyka, ale otwiera na nowe aspekty ważnej relacji między pedagogiką ogólną i religią. Jest to potrzebne nie tylko czytelnikom, którzy z różnych racji i w różnym stopniu zaangażowani są $\mathrm{w}$ refleksję naukową nad tym zagadnieniem, ale i szczególnie tym, którzy w jakiejkolwiek formie i stopniu interesują się relacjami kultury i religii ${ }^{1}$. Autor przyjął bardzo zobowiązujący styl i sposób prezentacji bogatego przecież materiału poznawczego: (re)konstrukcji zapomnianego wątku (jak to nazwał $\mathrm{w}$ tytule) dokonuje $\mathrm{w}$ oparciu o prace wybitnych myślicieli i uczonych: Herbarta i Schleiermachera. Jest to ważne wskazanie na wcześniejszą obecność religii w dyskursach pedagogicznych, zwłaszcza w kontekście współczesnych zaniedbań w tej płaszczyźnie.

${ }^{1}$ Należy odnotować, że w tym polu refleksji otrzymaliśmy ostatnio pracę pt. Pedagogika religii (2011), autorstwa ks. prof. Cypriana Rogowskiego z Uniwersytetu Warmińsko-Mazurskiego, który prezentuje w niej pedagogikę religii jako autonomiczną dyscyplinę naukową zajmującą się człowiekiem i jego związkami z rzeczywistością transcendentną. 
Każde zagadnienie z przedstawionych elementów problematyki relacji pedagogiki ogólnej i religii jest tu zaprezentowane w bardzo szerokim aspekcie: od wyjaśnienia pojęć, poprzez genezę poglądów filozoficznych, pedagogicznych i teologicznych obu autorów, do wskazania na wszystkie możliwie warstwy treściowe przedstawianej problematyki. Wiele miejsca zajęło autorowi prezentowanie tej części opracowania poszczególnych elementów przedstawianej problematyki, w której starał się wprowadzić w historię zagadnienia, wyjaśnić pojęcia, oświetlić przedpola. Na uwagę i podkreślenie zasługuje także kontekstualność refleksji, wpisanej w uwarunkowania sytuacji współczesnej pedagogiki ogólnej, kontekst społeczno-religijny i pedagogiczny.

Wydaje się, że wartość pracy ks. D. Stępkowskiego wykracza poza świat ścisłe naukowej refleksji i staje się ważnym elementem poważnej dyskusji nie tylko na temat styku rzeczywistości: religia-kultura, edukacja-religia, pedagogika i pedagogika religii, ale i sporów o obecność religii w systemie szkolnej edukacji, w wychowaniu młodego pokolenia. Czytelnik znajdzie tu bardzo ważkie argumenty dla uzasadnienia obecności elementu religijnego we współczesnej kulturze i edukacji.

\section{LA PRESENZAASSENZA DELLA RELIGIONE NEL DISCORSO PEDAGOGICO}

\section{RIASSUNTO}

I diversi e numerosi cambiamenti che si svolgono nel mondo odierno hanno pure il grande influsso sulla la forma della discussione della educazione. In essa si parla delle drammatiche sfide che stanno davanti all'educazione e minacce i quali essa deve affrontare. In fondo della discussione della situazione oppure della crisi della educazioine, pure della religione, si indica le cose più fondamentali come per esempio la relazione fra cultura e religione, l'educazione e religione, pedagogia e fiolosofia pedagogia e teologia. Tutto questo è ogni tanto il buon punto di partenza per la discussione della forma di educazione giusta per oggi. 